\title{
Entrepreneurial Challenges In Nigeria
}

\author{
${ }^{1}$ Olusanya, Samuel Olumuyiwa, ${ }^{2}$ Oyebo Afees Oluwatosin \\ ${ }^{1}$ Economics Department. Lecturer Lagos State University External System. \\ ${ }^{2}$ Marketing Departments. Lecturer Lagos State University External System.
}

\begin{abstract}
The study was conceptualized as an exploratory and quantitative one into the entrepreneurial challenges in a developing country like Nigeria, with focus on small scale business owners in Lagos, Nigeria. However, the research was premised on the assumption that entrepreneurs in developing countries like Nigeria face a lot of challenges hence the informal sector which they belong has not had the desired impacts on the growth and development of the economy. However, the study examine whether the challenges of entrepreneur has an impact on small business in Lagos State and to also examine whether the challenges of Entrepreneur has an influence on the quality of goods produced in Lagos, and finally to identify whether small business owner has an impact on the productivity in an Enterprise organization. More over, the study make use of primary data and questionnaire analysis and spearman's rank correlation was used as the estimation technique to test the three hypotheses, and the result study reveals that challenges of entrepreneur has a significant effect on small business in Lagos State and that the challenges of Entrepreneur has a significant on the quality of goods produced in Lagos State Nigeria and finally small business owner has a significant effect on the productivity in an organization. Moreover, our findings still reveal that the infrastructural constraints, financial problems which are key challenges confronting entrepreneur business owners are creation of failed governance in Nigeria. Successive governments and regimes in Nigeria have paid lip service to the problems of social infrastructure which are the engine hub of entrepreneurship and the opportunity cost of doing a good business in Nigeria, is the diversion of funds and energy to providing for these deficiencies. Bad leadership stifles an economy and creates an unfriendly investment atmosphere. Therefore, the study conclude and recommend that many Nigerian entrepreneur business owner in Nigeria do not understand nor appreciated the value of a stakeholder's analysis as a result they do not adequately understand how the impact of their business practices is felt in society, therefore the government and its agencies should also grant entrepreneurial development fund to financial institutions for disbursement to genuine entrepreneurs.
\end{abstract}

Keyword: Entrepreneurship, Small business owner, developing countries, loans and advances.

\section{Introduction}

Over the past decades, due to constant internal and external pressures of low capacity production, massive unemployment and poverty collapsed infrastructural facilities, poor governance structure, massive corruption, insecurity of life and property, political instability and poor macroeconomic management. The economy seems to have lost its focus and thus is yearning for quick intervention. However, the oil boom has destroyed and distorted our attitude to work (resource course) and this has affected the psychological quotient of an average Nigerian who prefers to avoid investments that require special expertise and innovation. In addition, the school curriculum is largely not geared towards equipping students with skills required for self-employment. Consequently, thousands of graduates from our tertiary institutions are roaming the streets in search of jobs that are non -existent. Nigeria is blessed with abundant human and natural resources which if properly harnessed would have turned this country into a developed economy. But given the massive corruption, lack of commitment, the dominant role of the public sector in the economic life of the nation, the country has lost opportunities for growth and sustainable development.

It is in an attempt to reverse this decline in the nation's economy, that current government policy of private sector led growth for job- and wealth creation which is anchored on Entrepreneurship is being pursued with vigor. In this new dispensation, government is to provide an enabling and conducive environment for the private sector to thrive. This could only come from a total change of attitude and a genuine embrace of entrepreneurial development which is a contemporary phenomenon now. Globalization calls for value creation and greater competiveness for Nigeria not to loose out. Youth and graduate unemployment can be drastically reduced if graduates/youths are empowered to be job creators or value adding employees not job seekers.

However, the whole idea about entrepreneurship is about self-employment, which will generate employment opportunities to others that must work with him as he cannot work alone. Entrepreneurship is the most effective method for bridging the gap between science and the market place, creating new enterprises, and bringing new products and services to the market. These entrepreneurial activities through implementation of new concepts. Drucker believes that what entrepreneurs have in common is not personality traits but a 
commitment to innovation. For innovation to occur the entrepreneur must have not only talent, ingenuity and knowledge but he must also be hardworking, focused and purposeful. Howard Stevenson of Harvard University defined Entrepreneurship as the pursuit of opportunities without regard to resources currently controlled. To be enterprising is to keep your eyes open and your mind active. It is to be skilled enough, confident enough, creative enough, and disciplined enough to seize opportunities that present themselves regardless of the economy. (Nwafor 2007). Robert Hisrich(1985) looked at entrepreneurship as the process of creating something different with value by devoting the necessary time and effort, assuming the accompany financial, psychological, and social risk, and receiving the resulting rewards of monetary and personal satisfaction.

Developments in entrepreneurship are sometimes seen as arising from three sources, namely: (a) from the contributions of economic writers and thinkers on the role of the entrepreneur in economic development and the application of economic theory.(b) from the psychological trait approach on personality characteristics of the entrepreneur, and (c) from social behavioral approach which stresses the influence of social environment as well as personality trait. For the purpose of this paper, we shall adopt the economists/managerial perspective to define entrepreneurship. McGrath and MacMillan in The Entrepreneurial Mindset identified five characteristics of habitual entrepreneurs: (i) They passionately seek new opportunities: are alert, always seeking for the chance to profit from change and disruption in the way business is done.(ii) They pursue opportunities with enormous discipline: are not only alert to spot opportunities, but make sure they act on them. Most maintain an inventory of unexploited opportunities and invest only if the competitive arena is attractive and the opportunity is ripe. (iii) They pursue only the very best opportunities and avoid chasing after every option: are ruthlessly disciplined about limiting the number of projects they pursue and go after a tightly controlled portfolio of opportunities in different stages of development.(iv) They focus specifically on adaptive execution: rather than analyzing new ideas to death, people with entrepreneurial mindset execute. Yet they are adaptive - able to change direction as the real opportunity, and the best way to exploit it evolves. (v) They engage the energies of everyone in their domain: involve many people, inside and outside the organization in the pursuit of an opportunity. They create and sustain networks of relationships rather than going alone, making the most of the intellectual and the other resources people have to offer and helping those people achieve their goals too.(Soyibo 2006).

However, Security Issues is one of the problem facing entrepreneur in Nigeria, and when there is no guarantee of security of lives and properties, it is difficult to run a successful venture, and unstable Political System in the country that brought about various crisis rocking the various governments at the three tier of government causes uncertainty and increases the risk associated with investments. More so, energy crisis which has led to many manufacturing firms shut down due to their inability to compete with foreign products. The reason is not far fetched; it is expensive running a factory with generators. In organized societies, generators are used as back-up plants to avoid disruptions in production process whenever there is power failure. The reverse is the case in Nigeria. Generators are the main source of electricity for all and sundry. Constant electricity supply is still a fairy tale. Further more, poor transportation system in Nigeria is quite poor. The roads are full of potholes, the railway system is not functioning anymore, the waterway is undeveloped while the air transport system is in crisis. It is therefore expensive moving both raw materials as well as finished products from one point to another. There are several others, but it is believe that if these ones are tackled first, the situation will greatly improve. The unfortunate thing is that most of these problems are not issues that can be tackled by the private sector. We simply need to get good leaders who are knowledgeable and are committed to the welfare of Nigeria into leadership positions at the various tiers of government. Starting from the local government level to the Federal government level. Moreover, another big challenge facing Nigerian entrepreneurs today is multiple taxation. Even though it is civic responsibility for every citizen and business organization to pay tax to the government, one begins to imagine if the whole margin on businesses will not be eroded considering the rate at which local government and state government agents pounce on shop owners and other small businesses to demand for taxes. Some of these taxes are questionable and there are duplications even when they are genuine (Ajayi, D 1993). Further more, proliferation of trade associations: the structures, government and regulations of so many of these trade associations especially at the grass root level can best be described as cumbersome. These associations are naturally supposed to protect, guide and encourage newcomers into the business but they instead place many burdens on new entrants and existing members. I wonder if they sometimes do all this to prevent new people from entering the business. Majority of these local trade associations are 'Self regulated and governments seem to care less about how they treat members as long as the association or union is duly registered. Therefore the objectives of the study is to examine whether the challenges of entrepreneur has an impact on small business in Lagos State, to also examine whether the challenges of Entrepreneur has an impact on the quality of goods produced in Lagos State Nigeria and finally to identify whether small business owner has an impact on the productivity in an organization. 


\section{The Meaning and Importance of Entrepreneurship}

\section{Literature Review And Theoretical Framework}

Entrepreneurship is a process; the purposeful and organized search for change, conducted after Systematic analysis of opportunities in the environment. Entrepreneurship is a philosophy precisely because it is the way one thinks, one cats and therefore it can exist in many situations be it business or government or in the filed of, education, science and technology or poverty alleviation (John Ogbor 2009). Peter Drucker (1985) sees it as directing the use of resources to progressive activities rather than for administrative efficiency. Here Drucker sees entrepreneurship as the mobilization of resources for advancement of the human life which is totally different from administrative efficiency. Drucker, the industrial health of a society depends on the level of entrepreneurship existing in it.

A country might remain backward not because of lack of natural resources or dearth of capital but because of lack of entrepreneurial talents or its inability to tap the latent entrepreneurial talents existing in the society.

Although there is a strong 'relationship between administrative efficiency, especially political efficiency and entrepreneurial growth.

This is evident in sub-Saharan African where there is a gross political inefficiency in contrast to their American, European and Asia-Tiger countries.

John Ogbor (2009) points out how the term entrepreneurship has been overused, misused abused and tacked into practically anything and everything from a particular view of the world. He argues that the concept of entrepreneurship must be understood from the perspective in which it was originally and historically produced. Originally, entrepreneurship is simply about the destruction of existing patterns of business behaviour and creating something new by capitalizing on an existing opportunity.

It has been documented that entrepreneurs intrinsically have altered the direction of national economies, industries or markets.

The importance of entrepreneurship and innovation to any economy is like that of entrepreneurship in any community. Entrepreneurial activity and the resultant financial gain are always of a benefit to a country (Kabeya 2001).

The idea behind the concept of entrepreneurship is about creating something 'new' that has value'. When an individual creates something new, the new creation is seen as an innovation. In the world of economic and business practice, the activity involves in the creation of something new is called entrepreneurship. Entrepreneurship, as one researcher puts it is seeing an opportunity and acting on it on the basis of organizing, the resources available to the entrepreneur or business owners. To this researcher, entrepreneurship is about foresight in resources mobilization.

Schumpeter (2000:pp 13-31) explains the concept of entrepreneur from functional dimension. According to him, the function of the entrepreneur is to reform or revolutionize the pattern of production by exploiting an invention or more generally an untried technological method of producing a new commodity or producing an old one in a new way, opening markets or new outlet for products, by organizing a new industry.

Implicit in Schumpeter's functional view of entrepreneur is the value addition objective.

A person who creates and delivers a value in an economic system, either in the informal or the organized sector of the economy, can be seen as an entrepreneur whenever that activity is undertaken strategically. For instance Benedict (1979) found that the growth of successful family entrepreneurs was dependent upon a strong authoritarian father and a closely knit family structure, with wife and children willing to submit to the father's rule. Other studies indicated that female entrepreneurs experience more operational and strategic impediment to success than their male counterparts and male-owned firms grew by women. Yet other surveys report higher rates of female entrepreneurial participation, both as owners and employees.

For example, Mead and Liedholm (2004) report female ownership rate of 48\% and employee 44\%. This according to them is a particularization of the micro and small enterprises.

Indeed, innovation, the act of producing something new is one of the most difficult tasks for the entrepreneur. I take not only the ability to create and conceptualize but also the ability to understand all the forces at work in the environment. The newness can consist of anything from a new product to a new distribution system to a method for developing a new organizational structure. To these researchers, the entrepreneur is a change agent. Although, Michael Dell did not invent the personal computer (PC). He was able to revolutionalize the industry by innovating on the industry chain-value: process innovation.

An entrepreneur is someone who identified an opportunity in an economic system, assembles the resources necessary to economic system, assembles the resources necessary to successfully exploit that opportunity and creates and delivers a value in an economic system. These resources according to Ogbor, (2009) include financial, human, technology, and organization. To Ogbor entrepreneurship is the process of combining scarce resources in new ways to respond to opportunities or provide solutions to a problem. 


\section{The Importance Of Entrepreneurs And Entreprebeurship In A Developing Country}

Many researchers have documented the role and importance of entrepreneurship in developing economies. Ogbor (2009) noted that small and medium-sized business are the engine of any economy as they are seen as lunching pad for entrepreneurship, businesses innovation and economic growth. Entrepreneurial ventures is the wheel with which an economy is driven because the large-sized companies, the multinational companies and the public sector have not been able to sustain livelihood of the majority of the populace in the developing countries.

Imbued in Ogbor's observation is the fact that SMEs, by their innovative approach to product and service delivery, impact more positively in the lives of people and organizations than the so called giant companies and public sector enterprises. Again, they are more evasive in their outreach and penetration. This view was corroborated by Brockhaus (1980) Collins and Moore (1994); and Tom Forest (1994).

Entrepreneurial development in developing countries is important because small business provides the basis upon which large corporations thrive. They perform this role by acting as suppliers and distributors to the larger companies. In this way they provide a linkage effect. Small businesses in many nations have always played the role as the link between large companies that produce and the consumers.

In many economies, the linkage between large scale producers and the consumers goes through individual small business operators. By providing an enabling environmental in which small businesses can act as the conduit between producers and consumers, the role of entrepreneur in the process of economics development can be enhanced. To this end, small scale entrepreneurial venture serve as mid-wives between the big corporations and the consuming public. But, big corporations nowadays are known for creating their own distribution outlets and marketing channels. The existence of manufacturer representatives, direct scales outlets are perhaps, innovation on part of big co-operation that tends to take away the function of small business firms. Again, because of financial and budgetary constraints, the public sector has been unable to make major investments capable of achieving economic growth in the developing countries. As new innovations and investments come from enterprises created, through individual initiatives, the role of entrepreneurial development has taken a new importance in developing economies. Ogbor and others have agued that public enterprises in developing countries have not been able to spur entrepreneurial development as a result of bureaucratic, political, cultural, and other institutional and historical reasons. Individual initiative in entrepreneurship should be seen as the challenges of economic development in the less and under developing economies.

\section{Theory Of Entrepreneurship}

Throughout this paper, we will discuss the new theory of information, and the entropy theory of value and how it is' related to entrepreneurs and experts. So far, there exists no concrete theory that can explain the success or failure of an entrepreneur. Through these new theories, we will show how the information that an entrepreneur possesses has to have a certain set criteria in order for them to be successful. We will show how previous entrepreneurs have succeeded, and where others have failed.

Throughout this paper, we will discuss experts and non experts. We will generalize the non experts as entrepreneurs, as most of them are not experts in their field, and also state that entrepreneurs are hobbyists or opportunists. They start out with the idea that they possess unique information that may be of high value and high utility to a given market, 'and want to work for themselves, mostly pursuing businesses that they themselves are interested in or greatly, enjoy.

Throughout it the paper is also stated generally, that most entrepreneurs accept a high degree of risk going into businesses for themselves, and are either are successful or fail miserably.

\section{The Value Of Information}

Through Jing Chen's research we have learned that the value of information is a function of probability and must satisfy the following properties: First, that the information value of two events is greater than the value of each of these events separate. Second, if two events are independent, the information value of the two events will be the sum of the two. Third, that information value of any event is non negative. The last property can be explained that information can be used in many different ways. The outcome could be negative, but the information that is used is either a positive value or has no value. For instance, if a person were to receive information about a certain stock that is expected to increase in the next trading period, he has the choice whether or not to use that information. If the stock goes down, and the investor loses money it is the use of the information that is negative, not the information itself. Along with the value of information is the degree of utility associated with the information. The higher the degree of utility, the more valuable the information is. For instance, information that has only one use is less valuable than information that has infinite amounts of usefulness. 
Within the theory of information, there are certain tendencies that apply to those who possess this type of information. In the following sections we will describe how experts and entrepreneurs react differently to new information, and how their behaviors are shaped by the information they possess.

\section{Theory Of Conservatism}

The theory of conservatism states that the more an individual becomes an expert, in their field; the less likely they will be to receive or accept new information. However, this follows the understanding that the more confident an expert is in their abilities to predict the future, or know their field, the less likely they will be to accept other types of predictions or information that could conflict with their own. The entrepreneur on the other hand, for the most part being a non expert, will not have this built in bias and confidence. Therefore, they will be more likely to accept changing information that may differ from theirs and in theory; this will increase the chance of the entrepreneur to be successful.

\section{Herding}

Herding describes the trait many experts and unsuccessful entrepreneurs have in copying existing behavior and information. For information to be highly valuable and useful, it needs to be unique and of high utility. If herding is used, the information value will be greatly decreased. Think of this principal as following the norm. New ideas are not easy to think up or implement, and therefore the majority of new information is just copies of already existing information.

\section{Over Confidence And Irrationality}

Experts are over confident about their own knowledge and base their future predictions on their own expertise and past events even though there may be signs that they are wrong. Therefore, if an entrepreneur is not an expert, he will not be overconfident, and will have a higher probability that he may accept new information that would contradict his own ideas. Past data is very important, but can be used too often to try and predict unpredictable events.

\section{Loss Aversion}

Loss aversion is a' principle that states most individuals will choose an event that has low returns, but has a higher probability of occurring, rather than another choice with a lower probability of returns. The experts, because they have more knowledge, and are more risk adverse, will be less willing to start something new that would have a high chance of failure. The entrepreneur on the other hand, is willing to accept more risk, which is the nature of entrepreneurship, in the hopes of higher returns. The entrepreneur is not risk adverse but a risk taker and he assumes the risk by starting his own company.

\section{Methodology}

The data that would be generated for the purpose of this research study is be basically primary data that would be used in generating questionnaire which will be administered to workers of selected entrepreneurs of small business owners in lagos State. However, the study population comprises 150 respondents (both Entrepreneurs of small business owners and their staffs) and it is made up of male and female entrepreneur, top management and middle as well as lower level of entrepreneur of small businesses in Lagos. More so, the population also has different material status from single to married employees.

\section{HYPOTHESIS 1}

\section{Research Hypothesis}

Null Hypothesis (Ho): Challenges of entrepreneur has no significant effect on the performance of small business in Lagos State.

Alternative Hypothesis (H1): Challenges of entrepreneur has a significant effect on small business in Lagos State.

\section{HYPOTHESIS 2}

Null Hypothesis (Ho): Challenges of Entrepreneur has no significant effect on the quality of goods produced in Lagos State Nigeria.

Alternative Hypothesis (H1): Challenges of Entrepreneur has a significant effect on the quality of goods produced in Lagos State Nigeria.

HYPOTHESIS 3

Null Hypothesis (Ho): Small business owner has no significant effect on the productivity in an organization. Alternative Hypothesis (H1): Small business owner has a significant effect on the productivity in an organization. 
The estimation technique for this research study is the use of spearman's rank correlation coefficient. Spearman's rank correlation coefficient is the statistical tool that 'will be used to analyze the research questions and also used to test the validity of the hypothesis of the research work. Further more, Spearman's rank correlation coefficient or Spearman's rho, named after Charles Spearman and often denoted by the Greek letter $\rho_{(\text {rho })}$ or as, is a non-parametric measure of statistical dependence between two variables. It assesses how well the relationship between two variables can be described using a monotonic function. If there are no repeated data values, a perfect Spearman correlation of +1 or -1 occurs when each of the variables is a perfect monotone function of the other. However, it can also be appropriate to use Spearman's correlation when both variables are continuous and the formular is as follows;

The formula is as follows:

$$
\mathrm{R}=1-\frac{6 \varepsilon d^{2}}{n^{2}(n-1)}
$$

Where $\mathrm{d}=$ the difference between the ranks of each pair. $n=$ Number of paired observations

TABLE 1

\begin{tabular}{|l|l|}
\hline Correlation range & $\begin{array}{l}\text { Strength } \\
\text { association }\end{array}$ \\
\hline \pm 0.70 to \pm 1.00 & Strong \\
\hline \pm 0.40 to \pm 0.69 & Moderate \\
\hline \pm 0.25 to \pm 0.39 & Weak \\
\hline \pm 0.10 to \pm 0.24 & Very weak \\
\hline \pm 0.06 to \pm 0.69 & None \\
\hline
\end{tabular}

Source: Nyang (2005)

DATA PRESENTATION AND ANALYSIS

Analysis of Questionnaire

TABLE 2

SEX DISTRIBUTION

Source: Field survey 2012

\begin{tabular}{|l|l|l|l|l|l|l|l|}
\hline RESPONSES & Frequency & $\begin{array}{l}\text { Cumulative } \\
\text { Frequency }\end{array}$ & $\begin{array}{c}\text { Percentage } \\
(\%)\end{array}$ & Responses & Frequency & $\begin{array}{l}\text { Cumulative } \\
\text { Frequency }\end{array}$ & $\begin{array}{c}\text { Percentage } \\
(\%)\end{array}$ \\
\hline Male & $\mathbf{9 8}$ & $\mathbf{9 8 . 0}$ & $\mathbf{6 5 . 3 3}$ & Single & $\mathbf{8 7}$ & $\mathbf{8 7 . 0}$ & $\mathbf{5 8 . 0}$ \\
\hline Female & $\mathbf{5 2}$ & $\mathbf{1 5 0 . 0}$ & $\mathbf{3 4 . 6 7}$ & Married & $\mathbf{6 3}$ & $\mathbf{1 5 0 . 0}$ & $\mathbf{4 2 . 0}$ \\
\hline Total & $\mathbf{1 5 0}$ & & $\mathbf{1 0 0 . 0}$ & & $\mathbf{1 0 0}$ & & $\mathbf{1 0 0 . 0}$ \\
\hline
\end{tabular}

From the result the result above, 98 out of 150 respondents are male and this gives $65.33 \%$ of the whole respondents and 52 out of 150 respondents are Female and this represent $34.67 \%$ of the total respondents. We can then conclude from the analysis above that there are more male respondents in the research study.

More so, it was also known from the result above that 87 out of 150 respondents are single and this constitutes $58 \%$ of the whole respondents while 63 out of 150 respondents are married and this gives $42 \%$ of the total respondents. Therefore we can conclude that there are more single respondents in the research than married respondents.

TABLE 3

AGE DISTRIBUTION
\begin{tabular}{|l|l|l|c|}
\hline RESPONSES & FREQUENCY & $\begin{array}{l}\text { Cumulative } \\
\text { Frequency }\end{array}$ & $\begin{array}{c}\text { Percentage } \\
(\%)\end{array}$ \\
\hline Below 25 years & 74 & 74.0 & 49.33 \\
\hline Between 25-35 years & 41 & 115.0 & 27.33 \\
\hline Ratwenn 36-45 vears & 21 & 1360 & 1400 \\
\hline 46 and above & 14 & 150.0 & 9.34 \\
\hline Total & 150 & & 100. \\
\hline
\end{tabular}

Source: Field survey 2012

The table above revealed that 74 respondents are below 25 years and this represents $49.33 \%$ of the total respondents while 41 respondents are between age $25-35$ years and this gives $27.33 \%$ of the total respondents. 
However, 21 respondents are between age 36-45 years and this gives $14 \%$ of the whole respondents while 14 respondents are between the age of 46 and above years and this constitutes $9.33 \%$ of the total respondents. From the above analysis we can then deduced that respondents below 25 years of age are more in the research study.

TABLE 5

EDUCATIONAL QUALIFICATION DISTRIBUTION

\begin{tabular}{|l|l|l|l|}
\hline RESPONSES & FREQUENCY & $\begin{array}{l}\text { Cumulative } \\
\text { Frequency }\end{array}$ & Percentage \\
\hline WAEC & 7 & 7.0 & 4.67 \\
\hline NCE/OND & 53 & 60.0 & 35.33 \\
\hline HND/B.SC & 73 & 133.0 & 48.67 \\
\hline M.Sc./MBA & 17 & 150.0 & 11.33 \\
\hline Tatal & 150 & & 1000 \\
\hline
\end{tabular}

Source: Field survey 2012

Table 5 above shows that $4.67 \%$ of the total respondents have WAEC qualification while $35.33 \%$ of the whole respondents have an NCE/OND qualification. However, $48.67 \%$ of the total respondents have HND/B.SC qualification while only $11.33 \%$ of the whole respondents have M.Sc/ MBA qualification; therefore we can then conclude that respondents with HND/B.Sc qualification are more in the research study.

TABLE 6

ANALYSIS OF RESPONDENTS BY NUMBER OF YEARS IN BUSINESS/ENTREPRENEUR

\begin{tabular}{|l|l|l|l|}
\hline RESPONSES & FREQUENCY & Cumulative Frequency & Percentage \\
\hline Less Than 1 year & 23 & 23.0 & 15.33 \\
\hline 1-5 years & 56 & 79.0 & 37.33 \\
\hline 6-10 years years and & 63 & 142.0 & 42.0 \\
\hline $\begin{array}{l}11 \text { be } \\
\text { above }\end{array}$ & 8 & 150.0. & 5.34 \\
\hline Total & 150 & & 100.0 \\
\hline
\end{tabular}

Source: Field survey 2012

Table 6 above shows that $15.33 \%$ of the total respondents have less than a year experience in the business while $37.33 \%$ of the whole respondents have between 1-5 years experience in the business of Entrepreneur. However, $42 \%$ of the total respondents have 6-10 years experience in the business of entrepreneur while $5.34 \%$ of the whole respondents have 11 years and above, therefore we can then conclude that respondents with 6 years and above in the business of entrepreneur are more in the research study.

TABLE 7

RESULT OF GENERAL QUESTIONS DISTRIBUTED TO THE RESPONDENTS

\begin{tabular}{|c|c|c|c|c|}
\hline Questions & Response & Frequency & $\begin{array}{l}\text { Cumulative } \\
\text { Frequecy }\end{array}$ & Percentage \\
\hline $\begin{array}{l}\text { Borrowing money from the } \\
\text { bank is preferable to finance } \\
\text { business }\end{array}$ & $\begin{array}{l}\text { SA } \\
\text { SD }\end{array}$ & $\begin{array}{l}140 \\
10\end{array}$ & $\begin{array}{l}140.0 \\
150.0\end{array}$ & $\begin{array}{l}93.33 \\
6.67\end{array}$ \\
\hline $\begin{array}{l}\text { Entrepreneurship to the } \\
\text { future of Nigeria economy is } \\
\text { promising }\end{array}$ & $\begin{array}{l}\text { SA } \\
\text { SD }\end{array}$ & $\begin{array}{l}122 \\
28\end{array}$ & $\begin{array}{l}122.0 \\
150.0\end{array}$ & $\begin{array}{l}81.33 \\
18.67\end{array}$ \\
\hline $\begin{array}{l}\text { Power Supply has been a } \\
\text { major problem }\end{array}$ & $\begin{array}{l}\text { SA } \\
\text { SD }\end{array}$ & $\begin{array}{l}150 \\
-\end{array}$ & 150.0 & 100.0 \\
\hline $\begin{array}{l}\text { Young people should be } \\
\text { encouraged to be } \\
\text { entrepreneur }\end{array}$ & $\begin{array}{l}\text { SA } \\
\text { SD }\end{array}$ & $\begin{array}{l}107 \\
43\end{array}$ & $\begin{array}{l}107.0 \\
150.0\end{array}$ & $\begin{array}{l}71.33 \\
28.67\end{array}$ \\
\hline $\begin{array}{l}\text { The cost of alternative } \\
\text { power supply in Nigeria is } \\
\text { very expensive }\end{array}$ & $\begin{array}{l}\text { SA } \\
\text { SD }\end{array}$ & $\begin{array}{l}150 \\
-\end{array}$ & 150.0 & 100.0 \\
\hline
\end{tabular}


Entrepreneurial Challenges In Nigeria

\begin{tabular}{|c|c|c|c|c|}
\hline $\begin{array}{l}\begin{array}{l}\text { Small scale business has } \\
\text { yielded } \\
\text { entrepreneurship }\end{array} \\
\text { better }\end{array}$ & $\begin{array}{l}\text { SA } \\
\text { SD }\end{array}$ & $\begin{array}{l}67 \\
83\end{array}$ & $\begin{array}{l}67.0 \\
150.0\end{array}$ & $\begin{array}{l}44.67 \\
55.33\end{array}$ \\
\hline $\begin{array}{l}\begin{array}{l}\text { One of the biggest } \\
\text { challenges }\end{array} \text { of any } \\
\text { entrepreneur is access to } \\
\text { capital. }\end{array}$ & $\begin{array}{l}\text { SA } \\
\text { SD }\end{array}$ & $\begin{array}{l}113 \\
37\end{array}$ & $\begin{array}{l}113.0 \\
150.0\end{array}$ & $\begin{array}{l}75.33 \\
24.67\end{array}$ \\
\hline $\begin{array}{l}\text { The future } \\
\text { Entrepreneurship } \\
\text { Development in Nigeria is } \\
\text { promising }\end{array}$ & $\begin{array}{l}\text { SA } \\
\text { SD }\end{array}$ & $\begin{array}{l}98 \\
52\end{array}$ & $\begin{array}{l}98.0 \\
150.0\end{array}$ & $\begin{array}{l}65.33 \\
34.67\end{array}$ \\
\hline Total & & 150 & & 100.0 \\
\hline
\end{tabular}

Source: Field survey 2012

Where SA - Strongly Agree, SD - strongly Disagree

From the table above $93.33 \%$ strongly agreed that borrowing money from the bank is preferable to finance business, while $81.33 \%$ strongly agreed that Entrepreneurship to the future of Nigeria economy is promising. More so, $100 \%$ of the whole respondents strongly agreed that Power Supply has been a major problem of Entrepreneurship in Nigeria while 71.33\% strongly agreed that Young people should be encouraged to be an entrepreneur in Nigeria.

However, $100 \%$ of the respondents strongly agreed that the cost of alternative power supply in Nigeria is very expensive while $55.33 \%$ of the total respondents strongly disagree that Small scale business has yielded better entrepreneurship in Nigeria. More over, $75.33 \%$ of the whole respondents strongly agreed that one of the biggest challenges of any entrepreneur in Nigeria is access to capital while $65.33 \%$ of the total respondents strongly agreed that the future of Entrepreneurship Development in Nigeria is promising.

TABLE 8

Result Of Spearman's Rank Correlation Coefficient For Research Hypothesis I, II And III

\begin{tabular}{|c|c|c|c|c|c|c|}
\hline & Q1 & Q9 & Q1 & Q9 & Q1 & Q9 \\
\hline $\begin{array}{lrr}\text { Spearman's } & \text { rho } & \text { Q1 } \\
\text { Correlation } & \text { Coefficient } & \text { Sig. } \\
\text { (2-tailed) } & & \\
\text { N } & & \end{array}$ & $\begin{array}{l}1.000 \\
150\end{array}$ & $\begin{array}{l}.811 * * \\
150\end{array}$ & $\begin{array}{l}1.000 \\
150\end{array}$ & $\begin{array}{l}.771 * * \\
150\end{array}$ & $\begin{array}{l}1.000 \\
150\end{array}$ & $\begin{array}{l}.704 * * \\
150\end{array}$ \\
\hline $\begin{array}{l}\text { Q9 Correlation C } \\
\text { N }\end{array}$ & $.811 * *$ & $\begin{array}{l}1.000 \\
150\end{array}$ & $.771 * *$ & $\begin{array}{l}1.000 \\
150\end{array}$ & $.704 * *$ & $\begin{array}{l}1.000 \\
150\end{array}$ \\
\hline
\end{tabular}

Source: SPSS Package

Decision Rule: If the $\mathrm{H}$ calculated is greater than $\mathrm{H}$ tabulated, we accept the alternative hypothesis and reject the null hypothesis. The tabulated value use here is $5 \%$ level of significance that is $* * \mathrm{P}<0.05$ and vice versa. However, from the spearman's rank correlation coefficient results for research hypothesis one, two and three value is given as $0.811,0.771$ and 0.704 which means there is a positive and strong relationships is established, therefore since the spearman's rank correlation coefficient calculated values $(0.811,0.771$ and 0.704$)$ are all greater than tabulated value using $5 \%$ level of significance $* * \mathrm{P}<0.05 \quad$ we then accept alternative hypothesis in all the three hypothesis and reject the null hypothesis in all the three hypothesis, then conclude that challenges of entrepreneur has a significant effect on small business in Lagos State for the first hypothesis and that the challenges of Entrepreneur has a significant on the quality of goods produced in Lagos State Nigeria for the second hypothesis and finally small business owner has a significant effect on the productivity in an organization, for the third hypothesis.

\section{Discussion And Conclusion}

The study was conceptualized as an exploratory and quantitative one into the entrepreneurial challenges in a developing country, with focus on small scale business owners in Lagos, Nigeria.

The research was premised on the assumption that entrepreneurs in developing countries face a lot of challenges hence the informal sector which they belong has not had the desired impacts on the growth and development of the economy. 
The study has attempted to answer the following questions among others: Does small scale business owners face the problem of necessary capital to run their business. Does the infrastructural and regulatory business environment in developing countries pose as obstacles to their operation?

However, the study reveals that entrepreneurs and small scale business owners face a lot of challenges which could impact negatively on their performance. Problems such as infrastructural inadequacies, regulatory challenges and corruption were implicated. Moreover, our findings reveal that the infrastructural constraints financial problems which are key challenges confronting small scale business owners is a creation of failed governance in Nigeria. Successive governments and regimes in Nigeria have paid lip service to the problems of social infrastructure which are the engine hub of entrepreneurship.

More so, is either as a result of bad electoral system which throws up corrupt elements as leaders in Nigeria, or a deliberate avarice to create wealth by the ruling class; the Nigeria firm has suffered poor and inadequate infrastructures. Roads are in deplorable state, electricity supply is almost non-existence, and health care facilities are grossly inadequate and sub-standard. School curricula are not tailored towards national needs but greed. This bureaucratic corruption which ahs been institutionalized in Nigeria results in under performance of government officials and institutions.

Thus, the opportunity cost of doing a good business in Nigeria, is the diversion of funds and energy to providing for these deficiencies. The provision of infrastructure and good business regulatory authorities is a function of a government financial constraint in one of the key challenges indentified as facing small scale business owners in Lagos state, Nigeria. This again, is a function of bad leadership. The per capital income of an average Nigerian is less than a dollar per day. Poor leadership styles rob the people of their economic strength therefore their income from engagement in productive efforts is less than expenditure hence no saving for investment. Bad leadership stifles an economy and creates an unfriendly investment atmosphere.

In conclusion, it was also found that many Nigerian business owners do not understand nor appreciated the value of a stakeholder's analysis as a result they do not adequately understand how the impact of their business practices is felt in society. In Lagos state, Nigeria, unethical business conduct manifest itself in various forms such as deceptive marketing practices, deceptive packaging and offering fake and adulterated products. More so, it is then recommended that Good governance at all levels should the order of the day, genuine and conscious efforts be made by all stakeholders in the Lagos state, and other states in Nigeria to institutionalized good governance and prudent resource management. The electoral process and democratic institutions in the land should be strengthened to guide against the emergence of pseudo-leaders whose aim is not to develop the nation but to loot the common wealth of the people. More so, the provision of key infrastructural facilities which are catalyst for business growth and development should be encouraged by government at all levels.

Further more, the operation of the country after the tenets of the principles of true federalism will help in this regard. Infrastructural planning and budgeting should be embarked upon by government at all levels. This should contain a comprehensive documentation of all priority infrastructural facilities to be provided by each tier of government annually. More over, big corporations and multinationals that operate in the state and the country should be encouraged to perform their social responsibility adequately; the problem of bureaucratic corrupting can be eliminated or reduced to its barest minimum by delegating the functions of certain offices or commissions, especially those that act as business regulatory to private authority outfits.

However, the government and its agencies should grant entrepreneurial development fund to financial institutions for disbursement to genuine entrepreneurs. This should be done at minimal interest rate and for long term, depending on venture, regular monitoring and maintenance of infrastructural facilities such as roods, electricity and health care centers, etc. are necessary to quickly put in order failing ones. In this way scare resources will be saved and financial empowerment and training in appropriate entrepreneurial skill is necessary, government should open such centers and make them accessible to the people and Entrepreneurs and business owners who are not literate in accounting and financial records should employ professional hands to do the job.

\section{Refrences}

[1] Akindele, S.T, (2005): “A. Critical Analysis of Alpha style of reference of Corruption and its problem in Nigeria Anthropologist Vol. 7, No.1, p. 11

[2] Carsrud, and R.W. Johnson, (1989), "Entrepreneurship a social psychological perspective" Entrepreneurship Theory and Regional Development: An International Journal Vol. 1, No.1, pp 21-31.

[3] Clifford Geertz, (1973): The interpretation of cultures (New York, Basic Books) Publication company. World Bank (2004) Doing business, a World Bank publication, pp 50-80, World Bank Press, washington, USA.

[4] Hindle, A.K. and M Lansodowne (2005) "Brave Spirits on New Paths: Toward a Globally Relevant paradigm of indigenous Entrepreneurship Research; Journal of 'Small Business and Entrepreneurship Vol. 18. No.2, Spring Pp 131-141.

[5] Hisrich, et al (2001): The Entrepreneur and Motivating Factors Academy of Management Review Vol. 8, No.2.

[6] John Ifediora, (2005): "The. Effects of Bureaucratic Corruption on Economic Development: The case of sub-Saharan Africa" Nigeria.

[7] Kabeya T (2001), culture, Entrepreneurship and Development in Africa, Paper presented at the international conference on the cultural Approach to Development in Africa (Dakar,

[8] Senegal) medium enterprises: an empirical assessment ", World Bank Economic Review vol. 7, No 1, pp65-83. 
[9] Machiko, N (2001) "Financing Enterprise Development in Sub-Saharan Africa" Cambridge Journal of Economics Vol. 25, pp 433367.

[10] Mark, F (1983) "The Definition and Assessment of political Risk in International Business: A review of the Literature" Academy of Management Review Vol. 8, No.2.

[11] Mead, K. \& Liedholm (2004) Gender issues in Entrepreneurship - A Critique. The Academy of Management Review Vol. 25, NO 1, pp.95 -111.

[12] Michell, R.K., Smith .B., K.W. Seawright (2000) Venture creation Decision”,Academy of Management Journal Vol. 43, No 5, lpp, 974-993.

[13] Ogbor, J.O (2009): Entrepreneurship in Sub-Saharan Africa A strategic Management Perspective Bloomigton, ldiana; USA.

[14] Okpako, .O.S (2003): The Impact of Privatization of Government Parastatals - The Nigerian case Pumak Press, Lagos, Nigeria.

[15] Pamela, .S. (2001); Interest and Attitude in Entrepreneurial Discourse Academy of Management, Journal Vol. 43, No 10, pp,10011127.

[16] Robinson, P.B., Stimpson D.V, et al., (1991): “An Aptitude Approach to the Prediction of Entrepreneurship" Entrepreneurship Theory and Practice Pp 13-31.

[17] Shane, .S. and Venkataraman .S. (2000): "The promise of. Entrepreneurship as a field of Research" The Academy of Management Review (Vol. 25, N01,) pp. $95-111$.

[18] Soyibo, .A. (1996): "Financial Linkage and Development in Sub-Saharan Africa: The Role of formal financial institutions in Nigeria", 001 Working paper 88 (London: Oversees Development Institute,).

[19] Bardo, O (1999) Entrepreneur, the way forward for development in Africa, a Journal of University of Ghana, faculty of Management sciences, Volume 3 pages 188-197, university press Accra, Ghana.

[20] Bygrave, M. O (2003) Financing small scale business through entrepreneurs involvement in Africa, a Journal of University of Leegion, faculty of management sciences, volume 2 pages 26-34, legion Press Publication limited, South Africa.

[21] Ajayi, O.O (2004) Challenges of Entrepreneur on small businesses in Nigeria, University of Ibadan, faculty of Education, vol 73, pg 44-51, University Press Ibadan, Nigeria.

[22] Lawal, O (1998) Population in broad perspective in Nigeria, a Journal of University of Lagos, Social science volume 3 pages 13 19, BBT Press limited, Nigeria.

[23] Barreto, o (1999) Entrepreneur way forward for development in Africa, a Journal of University of Jos, Management science, volume 3 pages 166-171, Macga Publication limited, Sweden.

[24] Ajayi, O.O (2004) Challenges of Entrepreneur on Small business in Nigeria, a University of Ibadan Publication, department of Educational Management, volume 3 pages 102-113, University Press Ibadan, Nigeria.

[25] Peter Drucker $(1985,2004)$ Administrative Efficiency in Nigeria, a textbook on Management, $3^{\text {rd }}$ edition Pages 23-29, Hillton Press limited, Nigeria.

[26] Schumpter (2000) Concept Entrepreneur in Africa, a textbook on Entreperneur, $2^{\text {nd }}$ edition pages 28-33, Newton Press limited, London.

[27] Benedict (1979) Growth and Entrepreneur in Nigeria, a University of Jos Publication, $4^{\text {th }}$ edition

[28] pages 33-37, Newton Press limited, London.

[29] Brockhaus (1980) Public Sector Enterprises in Nigeria, a presentation on public sector of Association of Economics students, Newton Press limited, London.

[30] Colins, Moore and Tom Forest (1994) Public Sector Enterprises in Africa, a textbook on Entrepreneurship, $1^{\text {st }}$ edition, pages 31-37, MDD Press, Belgium.

[31] World bank / IBDR (2006) Infrastructural facility in Africa, a world bank publication, 2006, world bank Press limited, Washington, USA.

[32] Levy (1993) Development of informal sector in Nigeria, a Journal of social sciences, University of Nigeria, volume 3 pages 22-31, University of Nigeria Press Publication, Nigeria.

[33] David Mcclellad and Winter (2007) Work Motivation in an organization, a textbook on Management, volume 3 pages 28-35, JJT Press limited, London.

[34] Dean, S. (2000) Entrepreneurial behaviour and its impact on business activities in Nigeria, a Journal of Management Sciences, Highton College of Management, Scotland, volume 4 pages 88-93, Highton Press limited, UK.

[35] Hunt (1991) Entrepreneurship activity in Nigeria, a broad perspective, a textbook on management, $2^{\text {nd }}$ edition pages 197-2007, Macgrawhill Press limited, London.

[36] Robert, H, Micheal, P and Dean S (2005) Business Opportunities in Nigeria, a Journal of Lund business school of Economics, $4^{\text {th }}$ edition pages 38-54, Lund Publication limited, Sweden.

[37] Venkataramen (2000) Economics development in Africa, a textbook on development Economics, $6^{\text {th }}$ edition, pages 231-276, Ventdit Press limited, Rusia.

[38] Shane (2001) Economics development in Focus, a textbook on development Economics, $5^{\text {th }}$ edition, pages 23-56, BBE Press limited, India.

[39] Waldinger et al (1990) Economics Research in India, a textbook on Research in Economics, $2^{\text {nd }}$ edition, Pages 48-76, Indiana Press limited, India.

[40] Masurel et al, Gregetto (2004) Ethnic Resources and Entrepreneurial behavior in Africa, a textbook on Management, $3^{\text {rd }}$ edition Pages 56-63 Newhill Press limited, Ghana.

[41] Osuala (1993) Research Methodology in Focus, a textbook on Research methodology, $3^{\text {rd }}$ editionpages 23-29 Macmillan Press limited, Nigeria. 